\title{
THE APPLICATION OF ENTREPRENEURSHIP PROGRAM AT PACKET C PKBM ASSOLAHIYAH
}

\author{
Heru Saleh $^{1}$, Aldian Hudaya ${ }^{2}$ \\ ${ }^{1}$ IKIP Siliwangi, Bandung \\ ${ }^{2}$ PKBM Cahaya Kahuripan Bangsa, Lembang \\ ${ }^{1}$ herusaleh096@gmail.com, 2oichidan@pkbmckb.org
}

\begin{abstract}
This research aims to describe the application of an entrepreneurship program to a community of packet $\mathrm{C}$ learners situated at PKBM Assolahiyah: the process, the results, the influencing factors, and the impacts toward the learning community. The subjects of this research include the program organizer, the tutors, and the learning community themselves. The data gathering methods include observation, interview, and study of documents. The data analysis method consists of three steps: data reduction, data display, and conclusion drawing. This research concludes that the 5 steps program enables its learning community to develop and display skills of entrepreneurship. The supporting factors include the availability of monetary equity, organizer support, strong motivation from the learning community and overall community support. The hindering factors include land availability limitations, community limitations, and constant funding availability issues. This program has economic impacts (enabling the community to start their own business, an increase of their household incomes, and the fulfillment of household needs), psychological impacts (the development of self-confidence and hard-working attitude in the community) and social impacts (encouraging the community to participate actively in community organizations, extending the community members' networks, and an ability to share their knowledge to the others).
\end{abstract}

Keywords: Packet C, Enterpreneurship, PKBM Assolahiyah

\section{INTRODUCTION}

Indonesia is among the densely-populated countries, making the top fourth place of being the mostly populated country in the world. According to Indonesia's Central Bureau of Statistics 2018 data, Indonesia is the home to approximately 261.890,9 thousand people, whilst the results of the 2010 Population Census (May) shows that Indonesia houses 237.641,3 thousand people. We can see that the 2010-2017 population growth rate is approximately $1,34 \%$. This infers that Indonesia expects a significant population number increase for the following years.

The highly populated country is also home to a vast number of social issues, among them is unemployment. This is also the root of many other social problems, such as criminal acts, poverty, health issues, education issues, among many others. On August 2010, Indonesia's Central Bureau of Statistics stated that there are approximately 8,96 million $(7,87 \%)$ of Indonesian citizens who are unemployed; most of them are situated in rural areas.

While the government endlessly puts considerable efforts to tackle unemployment issuessuch as providing free education for the unprivileged to enable them reach higher level educations, thus encouraging them to apply for jobs that were previously unavailable for 
them-these efforts needs further attention. For instance, the Indonesian government attempts building skill training centers such as sewing and handcraft classes to enable the educationally unprivileged to work with their skills. These efforts aim to cherish the number of enterpreneurs in Indonesia as an alternative to working in companies. Suryana (2010, p. 14) stated that for a country to be considered prosperous, the country must have at least $2 \%$ of its people working as enterpreneurs. Indonesia hopes to reach the percentage ratio, driving off the current percentage of enterpreneurs being approximately 1,56\% (BPS).

Among all the efforts tailored by the government, a notable one involves nonformal education through community entrepreneurship education. Indonesia's Ministry of Education and Culture (2013), through Public Law Number 20 Year 2003, stated that entrepreneurship education is provided by a nonformal education agency tailored to the needs and business opportunities in a community. Article 26 Paragraph 5 stated that the training and course is offered to the community that needs knowledge, skills, life skills, and attitude to develop self, profession, work, owning a business or to continue to a higher level of education. A Community Learning Center (CLC), or Pusat Kegiatan Belajar Masyarakat (PKBM) is a nonformal education agency with capabilities to hold such programs. UNESCO (in Kamil, 2011, p. 85) stated that a CLC/PKBM runs outside the formal education system, targets to both rural and urban communities, is organized by the community themselves, and enables communities to develop the skills they need to improve their life quality.

Narrowing our discussion coverage, we will visit Kabupaten Karawang, specifically PKBM Assolahiyah. Taking place in a rural community, the PKBM works with people who are mostly farmers, workers, and merchants graduated no higher than Junior High School. Some even left their elementary education unfinished, resulting in major incapabilities to improve their own prosperity. The community needs new skills to enact them out of the poverty zone.

Previously, there were a training of catfish farming but the results are not as the people expected. Numerous other programs held by the government in this community often cause doubts among the community; this goes to a point where if there were an entrepreneurship program, the community grows anxious of its results. Let's name an example: the catfish farming. Issues encountered include: (1) the analysis of community needs contradicts with the skills offered, learning process; and (2) the toughness of encouraging the people to change their 'employee' mindset to the entrepreneur's mindset. A PKBM's responsibility does not end where a program ends, for they still need to assist the community even after the program.

To that extent, the PKBM organizes another entrepreneurship training program, drawing from the catfish farming entrepreneurship training experience. From August until November 2014, the program now aims to extend what has achieved from the previous program, making it better, more complete, and wider in context. We, the researcher, draws interest toward this new program, specifically regarding how it impacts the Packet $\mathrm{C}$ learning community of PKBM Assolahiyah. We hope to see how the program benefits the learning community in accordance to a goal: to enrich their prosperity.

\section{Similar Researches}

This research draws inspiration primarily from Leatemia and Hudaya (2018). While this research differs in various aspects, including time, method, subject, and program in question, both researches attempt to evaluate the performance of a program. Leatemia and Hudaya uses 
the CIPP model to analyze if a doormat creation training program in PKBM Cahaya Kahuripan Bangsa benefits its learning community. Insofar, their findings show that the program benefits in that individuals participating in the program become more independent, capable, and well-performing in context of their daily life in their respective societies. Both the catfish farming program and the doormat creation program aims for the same goal: to create more independent, more capable individuals with the ability of opening their own business using the skills they have. In the context of their program, Leatemia and Hudaya found that primary factors influencing program performance include participants' motivation, monetary funding, and infrastructure — of which the three were deemed working well —and a relationship with the corporate world to enable selling created doormats to a wider market of name. In addition, they also noted that participants design and implement their own learning process, while an experienced instructor serves as a facilitator to guide them to reach the goals they set for themselves. This enables participants to participate more willingly and actively, contributing to the sucess of the process.

\section{METHOD}

This research is a descriptive research taking qualitative approach that is capable to provide complete description regarding its findings. It takes place at PKBM Assolahiyah, from January 2017 until April 2018. We determine the research subject purposively, in order to select learners who had participated the first and present catfish farming training program, and active, capable tutors. In addition, subjects include the program organizer who will be interviewed when deemed plausible.

Before actual data gathering, we conduct a premature observation in order to capture a brief image about the PKBM in question. The information we've gathered in this premature observation is present in the research proposal, and is also used to construct research and data guides. Afterwards, we use the guides in conducting data gathering through observation, interview, and document studies. Research instruments are in use to ensure the gathered data is consistent in topic and theme. We conduct data analysis from the beginning of data collection until the final data collection to make sure analysis stays coherent and consistent while getting sufficient data.

In a qualitative research, the researcher plays a pivotal role as both the instrument and the key (Sugiyono, 2008; Malik \& Hamied, 2016). In other words, the researcher is a human instrument with almost absolute control in defining the research focus, informant selection, data gathering, data quality assessment, data analysis and conclusion drawing. We may not neglect the fact that qualitative researches are inductive in natural, as shown on the following diagram: 


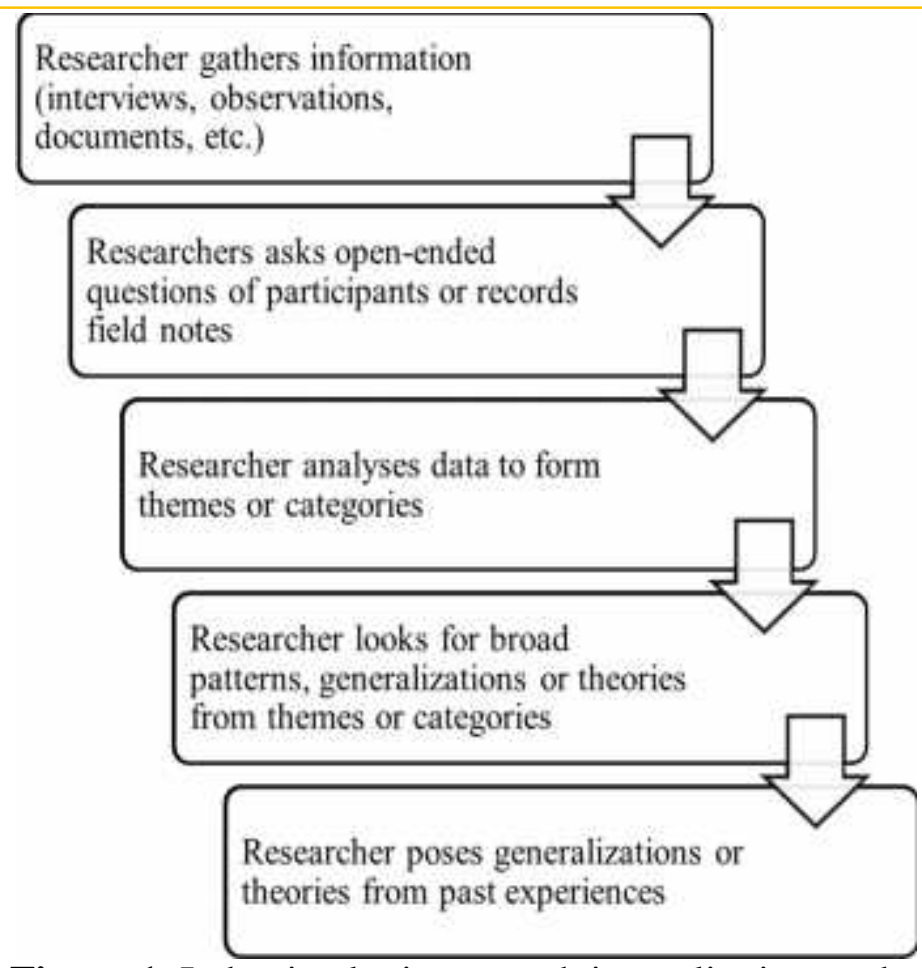

Figure 1. Inductive logic research in qualitative study.

Source: Malik \& Hamied (2016, p. 173)

From the diagram above we may argue that this research may not be perfectly replicated, even though conducted in the very same context, subject, time, place, etc. As with all qualitative researches, the characteristics of this research is unique to this particular topic, subject, time, place, context-basically, this research is unique and cannot be perfectly replicated to achieve the very same results.

The observation and interview will focus on what the Packet $\mathrm{C}$ learning community feels about the learning process and how it impacts their life, done in a periodical, case-by-case basis in the specified time span (refer to the first paragraph of the Methods section). Missing data gathered through observation and interview will be completed through means of document studies-from pictures and videos about the training process, information regarding the PKBM and Packet $\mathrm{C}$ program, and other notes that we deem required in order to complete the information needed for data analysis.

Regarding data analysis, we pass the information we've gathered through three methods: data reduction, data display and conclusion drawing. We thoroughly read all information gathered through the three data gathering means and redact all unnecessary information, unlinked/orphan information (that is, information that does not have any relation to other information points), and simplify repeated information. After reduction, we display the data in a systematic structure that is easy to read and understand, easing the process of conclusion drawing. Through the systematic display of data, we conclude important points in accordance to the goals of this research.

\section{RESULTS AND DISCUSSION}

\section{Results}


The program has been successfully conducted from August until November 2017, following all the guidelines present in The Technical Guide to Community Enterpreneurship Training published by The Office of Courses and Training, of The General Directorate of Early Childhood, Informal and Non-Formal Education, of the Indonesia Ministry of Education and Culture. As stated in previous paragraphs, the training involves practices in catfish farmingfrom breeding until maturity-and its entrepreneurial opportunities. The program consists of five phases:

a. Planning - a phase where the organizers identify, socialize, held meetings, and determine the program's plans. This includes the program's proposal, goals, graduate qualities and expectations, development of curriculum and course materials, preparation of courseworks, arranging financial funds, tutor recruitment, and finally learning community recruitment;

b. Executing - making sure the program runs as intended, the organizers put a special focus toward facilities and infrastructure, process quality measured through tutor's attemdance and their abilities to guide the process, including the methods they employ;

c. Monitoring - this is done to measure the success of the program, done by organizers as a mean to ensure the program performs as they expect them to. Where mistakes and obstacles discovered, the organizers take appropriate actions accordingly. Aspects monitored include program preparation, program execution and tutor guidance.

d. Evaluating - tutors do this to evaluate the performance of the participants. In the program, tutors evaluate their theoretical abilities through objective tests, skills through practice evaluation, and business performance evaluation.

e. Assistance-after the program, the organizers assist the learning community in a periodical basis to make sure they can run their own business using the skills they obtained through the training. The organizers supply an initial amount of funds as a base for the community to establish the business.

Compared to their qualities before participating into the program, the learning community, in a present time, displays adequate abilities and performances in establishing a new business using the skills they obtained, predicting market opportunities, preparing a decent land and/or pond, choosing a great catfish as a base, seeding, maintaining, tending, warding off pests, managing the catfishs' development stages, marketing the harvested catfishes, and tending to post-harvest pond tending.

Supporting factors include funds availability, organizers' support, motivation that comes from within the participants, and community support. Hindering factors include land limitations, community participation issues and funding related issues.

The learners admit they feel numerous benefits from the programs compared to the first catfish farming. In general, they feel a significant benefit in the dimensions of skills and knowledge. As a whole, we divide the impacts to three categories:

a. Economy-owning their own business, an increase in economic household incomes, and fulfilling household needs;

b. Psychology - the increase of confidence and hard-working entrepreneur attitude shown; dan

c. Social - the increase of community participation in community organizations, widening networks and relations, and the increase of capacity to an extent that they can share their knowledge to the others. 


\section{Discussion}

Enterpreneurship is a dynamic process to increase exchange value of goods and services to improve prosperity. Drucker (1994) and Saragih (2017) defines entrepreneurship as a skill to create something new and different. Scarborough, Zimmerer, \& Naumes (1996, p. 51) argue that entrepreneurship is a process to apply creativity and innovation to solve problems and seek opportunities faced by every person in their daily life context. The core of entrepreneurship is the ability to create something new and different through creative thinking and innovatice actions to create opportunities.

Zimmerer and Scarboroug (2005) formulates the benefits of being an entrepreneur:

1. Offers opportunities and freedom to control one's path of life;

2. Enables openings to conduct social change: businessmen found new and exciting ways to combine their form of care toward a variety of social and economic issues, hoping that their efforts contribute to a better life;

3. Creates chances to achieve full self potential: owning a business gives power, spiritual rise and establishing new business following one's interests or hobbies;

4. Exposes breaks to achieve highest, most optimal earnings;

5. Enacts opportunities to actively take a role in the society and receive credits of their work; and

6. Make openings available to do something to one's likings and grows happiness in doing so.

Community Enterpreneurship Education is a program offering educational services focusing on entrepreneurship and entrepreneurial skills organized by nonformal education agencies. Drawing from the brief description above, we agree that the program mainly focuses on enabling its participants to develop something new to unbind themselves from economic and social issues. The program we analyze, the catfish farming entrepreneurship training program, comprises of five phases as mentioned briefly above.

The first phase, the planning phase, consists of identifying available potentials, program socialization, coordination meetings and program establishment. The organizers do this completely according to the availability and condition of the community, making sure each and every aspiration is accounted in the program's planning and design. Thus, the catfish farming idea was born from numerous considerations.

The second phase, execution, is according to the National Competency Standards of Enterpreneurship Programs: a minimum of 200 hours; for each hour, 45 minutes is for theories and 60 minutes for practice. The curriculum is developed from the information gathered from the planning phase, including tutors' suggestions, national standards, tailored to meet the community's needs and expectations. There are a number of 10 people who enrolled to the program, solidified to one group. There are two tutors, one focusing on theoretical sessions and one other for practice sessions.

This program applies both traditional lecturing and live practice sessions as methods. Coursework and content delivered covers entrepreneurship and catfish farming skills. This goes on to the third phase, monitoring, where tutors actively monitor their community in a per session basis and organizers in a scheduled basis to make sure the program runs as they 
expected. Where problems arise, tutors, community and organizers sit together and formulate an appropriate action to be taken accordingly.

The final phase of the program is evaluation. This is done by the tutors, both covering the theory sessions as a mean to measure knowledge quality and practice sessions as a mean to measure practical skill quality. In addition, tutors also evaluate the community's entrepreneurship performances as a part of the entrepreneurship dimension of this program. The organizer and tutors use both objective, paper-based tests and non-test evaluations accordingly and in a per-case basis.

Assistance is given after the community finishes their program. In this phase, organizers make sure the community can establish their own business, even cashing out funds as a basis for them to open a new business. Each assistance session lasts 60 minutes, with a total of 60 sessions/hours maximum, assuming twice a week-though this ultimately depends on the community's availability and needs.

The above practice aligns with entrepreneurial orientation (EO). As suggested by Dike (2008) and Adegbuyi, Oladele, Iyiola, Adegbuyi, Ogunnaike, Ibidunni, \& Fadeyi (2018), entrepreneurial orientation is an organization's strategic orientation that refers to detailed entrepreneurial aspects of policymaking styles, approaches and practices. It sums up the features of an entrepreneurial firm. Fasua (2006 in Adegbuyi, et al., 2018, p. 2) stated that's an entrepreneurial firm is one that is involved in innovation, undertakes risky ventures and is first to come up with proactive steps, being competitors to it. By providing the community with all they need to start a new business, the program aligns them into becoming an entrepreneurial firm, enabling them to involve themselves in innovation, undertake risky ventures and come up with proactive steps way ahead from their competitors. Therefore, this program supports the formation of new, small entrepreneurial firms and supports their growth and development.

Sudjana (2006, p. 95) defines both positive and negative impacts in terms of their dimensions. Where an impact supports a society to fulfill their goals and needs, it is a positive impact, and where an impact hinders a society to do so, it is a negative impact. Both positive and negative impacts as stated on the previous section have been gathered and concluded from the participants' point of view and expressions during interview sessions and observation data. This also reflects that among all the other reasons this program is organized, the very core issue they want to tackle is both economic issue (unemployment, underpayment, low wages, and lack of enterpreneurs) and social issues (all social issues arose from the economic issues, such as crimes driven by unemployment (Chambliss \& Eglitis, 2019)).

Lastly, the organization of this program has caused a shift of professions among the community. Now it has become commonplace to discover local people around the PKBM area running their own business, either as a primary profession or as a secondary carreer. This social change, as suggested by Yilmaz \& Yilmaz (2019), is driven by a social vision. It sees the opportunities beyond what is present, and transforms the individual into a change agent, influencing their surroundings. Values are also influential on societal ideal behaviors, thus making the new enterpreneurs a role model for the previously uninterested to improve their own qualities of life. This also drove an increase in active community participation in societal 
organizations. This participation transformed them into becoming active participants, thus enabling them for further improvements in many dimensions of their life.

\section{CONCLUSION}

This research concludes that the 5 steps program enables its learning community to develop and display skills of entrepreneurship. The supporting factors include the availability of monetary equity, organizer support, strong motivation from the learning community and overall community support. The hindering factors include land availability limitations, community limitations, and constant funding availability issues. This program has economic impacts (enabling the community to start their own business, an increase of their household incomes, and the fulfillment of household needs), psychological impacts (the development of self-confidence and hard-working attitude in the community) and social impacts (encouraging the community to participate actively in community organizations, extending the community members' networks, and an ability to share their knowledge to the others).

\section{REFERENCES}

Adegbuyi, A.A., Oladele, O.P., Iyiola, O.O., Adegbuyi, O.A., Ogunnaike, O.O., Ibidunni, A.S., \& Fadeyi, O.I. (2018). Assessing the influence of entrepreneurial orientation on small and medium enterprises' performance. International Journal of Entrepreneurship, 22(4), 1-7.

Badan Pusat Statistik. (2018). Statistik Indonesia 2018. Badan Pusat Statistik.

Chambliss, W. J., \& Eglitis, D. S. (2019). Discover sociology. SAGE Publications, Incorporated.

Dike, B.E. (2008). Is small and medium enterprises (SMEs) a viable business? International Journal of Academic Research in Business and Social Sciences, 2(1), 2222-6990.

Drucker, P.F. (1994). Innovation and Enterpreneurship. New York: Harpercollins Publisher.

Kamil, M. (2011). Pendidikan Nonformal (Pengembangan melalui Pusat Kegiatan Belajar Mengajar di Indonesia). Bandung: Alfabeta.

Leatemia, L. S. D., \& Hudaya, A. (2018). Evaluating the doormat creating life skill program in the Cahaya Kahuripan Bangsa Community Learning Centre Lembang. Empowerment, 7(2), 179-192.

Malik, R.S., \& Hamied, F.A. (2016). Research Methods: A Guide for First Time Researchers. Bandung: UPI Press.

Saragih, R. (2017). A Membangun Usaha Kreatif, Inovatif dan Bermanfaat melalui Penerapan Kewirausahaan Sosial. Jurnal Kewirausahaan, 3(2), 26-34.

Scarborough, N. M., Zimmerer, T. W., \& Naumes, W. (1996). Effective small business management (Vol. 2). Upper Saddle River, NJ: Prentice Hall.

Sudjana, D. (2006). Evaluasi Program Pendidikan Luar Sekolah. Bandung: PT Remaja Rosdakarya.

Sugiyono. (2008). Metode Penelitian Kuantitatif, Kualitatif dan R\&D. Bandung: Alfabeta.

Suryana, Y. (2010). Kewirausahaan (Pendekatan Karakteristik Wirausahawan Sukses). Jakarta: Kencana.

Undang-Undang Sistem Pendidikan Nasional, 2013.

Yilmaz, A., \& Yilmaz, H. U. (2019). Social Value and Sociological Perspective on Social Entrepreneurship. In Creating Business Value and Competitive Advantage With Social Entrepreneurship (pp. 21-47). IGI Global.

Zimmerer, T. W., \& Scarboroug, N. M. (2005). Essentials of entrepreneurship and small business management. Prentice-Hall. 